\title{
Effects of the Entrepreneurial Strategic Orientation of Social Enterprises on Organizational Effectiveness: Case of South Korea
}

\author{
Changwon Cho ${ }^{1}$, Boyoung $\mathrm{Kim}^{1, *(\mathbb{D})}$ and Sungho Oh ${ }^{2}$ (D) \\ 1 Seoul Business School, aSSIST University, Seoul 03767, Korea; jjack3@stud.assist.ac.kr \\ 2 HR Division, Hitachi-LG Data Storage, Seoul 08503, Korea; sungho.oh@hlds.co.kr \\ * Correspondence: bykim2@assist.ac.kr; Tel.: +82-10-4046-2428
}

check for updates

Citation: Cho, Changwon, Boyoung Kim, and Sungho Oh. 2022. Effects of the Entrepreneurial Strategic

Orientation of Social Enterprises on

Organizational Effectiveness: Case of South Korea. Administrative Sciences 12: 19. https://doi.org/10.3390/ admsci12010019

Received: 27 December 2021

Accepted: 19 January 2022

Published: 24 January 2022

Publisher's Note: MDPI stays neutral with regard to jurisdictional claims in published maps and institutional affiliations.

Copyright: (C) 2022 by the authors. Licensee MDPI, Basel, Switzerland. This article is an open access article distributed under the terms and conditions of the Creative Commons Attribution (CC BY) license (https:// creativecommons.org/licenses/by/ $4.0 /)$.

\begin{abstract}
This study aims to empirically verify whether the entrepreneurial strategic orientation of social enterprises has any effect on organizational effectiveness with the mediation of dynamic capabilities. In the consideration of social enterprises' features, strategic orientation consisted of social value orientation, entrepreneurial orientation, and market orientation. Dynamic capabilities consisted of absorption capacity and coordination capacity, and organizational effectiveness was comprised of job satisfaction and organizational commitment. An online questionnaire survey targeted 228 employees of Korean social enterprises. The survey results were analyzed using a structural equation. As a result of the analysis, entrepreneurial orientation and market orientation significantly affected absorption capacity, but social value orientation did not affect it. Social value orientation and market orientation significantly affected coordination capacity, but entrepreneurial orientation did not affect it. Absorptive capacity and coordination capacity affected organizational effectiveness, and the hypotheses were adopted. Consequently, it was revealed that market orientation had the most significant effects on social enterprises' dynamic capabilities and organizational effectiveness. It was confirmed that social value orientation and entrepreneurial orientation revealed differences depending on the absorptive capacity and coordination capacity of dynamic capabilities.
\end{abstract}

Keywords: social enterprise; strategic orientation; dynamic capabilities; absorptive capacity; coordination capacity; organizational effect

\section{Introduction}

Social enterprises, typical social economies, have spread dramatically from the 1980s, particularly in Europe and the USA (Defourny and Nyssens 2010). Social enterprises developed as nonprofit companies, which had faced financial burdens, adopted a commercial profit mode in the USA (Alter 2007; Kerlin 2006). Although the concepts and organizational types of social enterprises vary depending on the background of their advent and system characteristics by country, social enterprises currently exist in 43 countries in the EU, North America, Asia, the Middle East, and Africa (Defourny et al. 2021). In Korea, the government has been certifying social enterprises since the Social Enterprise Fostering Act in 2007. The social enterprises formally certified by the Ministry of Employment and Labor were 3142 as of 2021 (Korea Social Enterprise Promotion Agency 2021).

Alter (2007) explains that social enterprises are located between nonprofit organizations pursuing social welfare logics, and public, private companies emphasizing profitability, wherein the nonprofit and profit-making enterprises are classified with a spectrum deployed in both extremities. If the synergy between social welfare logics and commercial logics increases, social enterprises' innovation and performance can be enhanced. Therefore, a need to seek organizational transformation reflecting new needs has been emphasized, through which social missions can be upheld, and innovative corporate performance can take place (Soh 2012; Young and Kim 2015). 
Consequently, studies to overcome conflicts between social welfare and commercial logic within organizations are being carried out for the sustainability of social enterprises (Battilana and Dorado 2010). From an institutionalism perspective, the importance of social enterprises as a hybrid organization pursuing both social welfare and commercial logic is emphasized (Besharov and Smith 2012; Pache and Santos 2013; Doherty et al. 2014). In this regard, entrepreneurial strategic orientation leading social enterprises is stressed, and the reason is that strategic orientation, a business approach for social enterprise entrepreneurs who try to obtain scarce resources and organizational identity, has a significant effect on management performance or sustainability (Gatignon and Xuereb 1997; Liu et al. 2014). Social enterprises can secure a continuous competitive edge like general companies, if proper resource deployment and business goals are established based on entrepreneurial strategic orientation (Barney 1991).

Previous studies assert that dynamic capabilities should preemptively develop social enterprises within the changing macro environment (Oliver 1991; Pache and Santos 2013). Dynamic capabilities have been researched as a series of processes recognizing a business opportunity, seizing it as commercialization, and properly redeploying resources (Teece et al. 1997; Teece 2007; Eisenhardt and Martin 2000; Pavlou and El Sawy 2011). Recently, dynamic capabilities are gaining attention to cope with rapidly changing environments due to technological development. The dynamic capabilities aim to overcome the uncertain management environment, and they have been frequently discussed for the research of general private companies; however, discussions are lacking in the social enterprise research field (Santos 2012; Grassl 2012; Bull and Ridley-Duff 2019).

This study aimed to empirically analyze the effects of social enterprise entrepreneurial strategic orientation on organizational effectiveness within the changing environment, with the mediation of dynamic capabilities. To draw organizational effectiveness, such as the organizational satisfaction or organizational commitment of the members within a social enterprise, a leader's strategic orientation is important as a business activity beyond social ideology, value, or ideological problems. Primarily, this study aims to prove that strategic orientation is affected by an organization's dynamic capabilities.

With the dynamic capabilities of social enterprises, this study aims to seek a concrete development direction on organizational capability consolidation for enhancing social enterprises' organizational effectiveness. As social enterprises' dynamic capabilities, this study investigates the effect of the absorptive capacity and the coordination capacity to entrepreneurial strategic orientation and organizational effectiveness.

\section{Theoretical Background and Hypothesis Development}

\subsection{Social Enterprises and Entrepreneurial Strategic Orientation}

Strategic orientation means a firm's strategic direction inducing its appropriate behaviors to attain continuous and excellent business performance (Gatignon and Xuereb 1997). Liu et al. (2014) reported strategic orientation as the process, implementation, principle, and decision-making style leading to organizational acts responding to the external environment. Entrepreneurial strategic orientation can be understood as leading proper resource distribution and organizational behaviors to create new values and a continuous competitive edge in the uncertain management environment.

Jeong et al. (2006) presented the major factors of strategic orientation as customer orientation, while technology orientation (Gatignon and Xuereb 1997) also presented that technology orientation, customer orientation, and competitiveness are sub-concepts of market orientation. In other previous studies, the components of strategic orientation are reconfigured, centered on market orientation, entrepreneurial orientation, and technology orientation. Nicholls and Cho (2006) defined social entrepreneurial spirit as three factors: market orientation, innovation, and sociability. This study examines entrepreneurial strategic orientation for social enterprises, centered on social value orientation, entrepreneurial orientation, and market orientation. 
Jang and Ji (2021) defined social value orientation as a trend pursuing social values as the degree and recognition for social value realization. Miles et al. (2013) insisted that social value orientation significantly affected social performance. Bull and Ridley-Duff (2019) asserted that social value orientation is essential for attaining continuous performance. Namely, they explained that social value orientation should reflect social enterprises' nature to pursue social mission preferentially. Therefore, Dwivedi and Weerawardena (2018) presented five dimensions of social entrepreneurial spirit innovativeness, proactiveness, risk management, effectual orientation, and social mission orientation, in terms of social enterprise entrepreneurial strategic orientation.

Entrepreneurial orientation is "a disposition for a company or an entrepreneur that wants to create values through the market opportunity to act innovatively, proactively, and in a risk-taking way" (Wiklund and Shepherd 2003; Zahra and Covin 1995). It is based on the same entrepreneurial spirit (which made innovations, proactiveness, and risk-taking) that Miller (1983) presented as a configuration concept. Lumpkin and Dess (1996) defined entrepreneurial orientation as competitive aggressiveness and autonomy, in addition to innovation, proactiveness, and risk-taking. Lumpkin and Dess (1996) researched the entrepreneurial orientation concept from entrepreneurs' processes, practices, and decision-making activities. The recent studies that targeted nonprofit organizations propose that construct is essential in entrepreneurial spirit (Morris et al. 2011). They assert that nonprofit corporations or social enterprises need entrepreneurial orientation for competency consolidation as a business organization (Austin et al. 2006).

Market orientation is a concept that allows companies to have a competitive edge and exert high profits by quickly identifying consumer needs change, and paying sharp attention to competitors' movements (Slater and Narver 1995). The organizational, cultural, and behavioral perspectives suggested by Narver and Slater (1990), and the market information perspective of Kohli and Jaworski (1990), have presented study results on market orientation. Bhattarai et al. (2019) showed that market orientation significantly affects socioeconomic performance through empirical studies targeting British social enterprises. Because social enterprises should compete with profit-making enterprises and social enterprises in the same industry for a greater share of the market, social enterprises are essentially needed in processes for an organization or management. Boehm et al. (2011) reported that the market orientation of people offering social services is vital to meet beneficiary needs.

\subsection{Entrepreneurial Strategic Orientation and Dynamic Capabilities}

Strategic orientation allows companies to build up dynamic capabilities amid the rapidly changing management environment (Zhou and Li 2010). Strategic orientation closely affects the shaping of the organizational learning environment, which is a process in which acquired information is shifted into knowledge (Zhou et al. 2005). Previous studies suggest that organizational orientation secures and rearranges resources, and shapes the foundation of changing dynamic capabilities (Gatignon and Xuereb 1997). For unstable social enterprises to secure a continuous competitive edge and enhance organizational effectiveness due to their hybrid nature, they should secure dynamic capabilities and strategic orientation (Prasetyo and Khiew 2016; Vittoria and Persico 2010). The reasons are that social enterprises are unfavorable in securing resources compared to profit-making enterprises, need dynamic capabilities to innovatively find business opportunities, actively use scarce resources, and promote organizational stability through conflict control within the organizations. Thus, Vézina et al. (2019) defined dynamic capabilities as a series of social innovation processes, including sensing social demand, capturing its industrialization, and innovatively reconfiguring integrated knowledge. 
Jantunen et al. (2005) explained that higher entrepreneurial orientation might positively affect the construction of dynamic capabilities, acquiring and reconstituting scarce resources in the unclear management environment, and securing a competitive edge. Slater and Narver (2000) examined the relationship between market orientation and dynamic capability, and Hult et al. (2003) reported that the relationship between social value orientation and dynamic capabilities is significant.

Weerawardena and Mort (2006) emphasized that social mission is not a sacred goal, but should be understood as a role within the competitive organizational environment. They asserted that the social mission is the center of social enterprises' overall strategies, pursuing a balance between social logic and economic logic to find business opportunities, grow services, and survive in the competitive market. The importance of social value orientation was explained as a strategic factor supporting dynamic capabilities that enhance organizational effectiveness by mobilizing the organization's internal resources amid the management environment of social enterprise with high uncertainties.

Zhou et al. (2005) paid attention to researching corporate capacity to maintain sustainable advantage amid the rapidly changing market environment, and discovered that organizational learning, a core of dynamic capabilities, plays a partial mediation role between strategic orientation and corporate performance. Teece et al. (1997) defined dynamic capabilities as the capacity to integrate, build, and reconfigure an organization's internal and external capacity to respond to the rapidly changing environment. Utilizing the capacity of sensing business, seizing concrete opportunity, and managing threats/transforming continuous assets becomes an essential factor of corporate activities in terms of dynamic capabilities to create and expand unique corporate tangible/intangible assets (Teece 2007).

The subconstruct of dynamic capabilities has been diversely defined. Eisenhardt and Martin (2000) defined the components of dynamic capabilities, such as sensing, seizing, and reconfiguration. Pavlou and El Sawy (2011) presented dynamic capability factors such as corporate sensing, learning, integration, and adjustment. Wang and Ahmed (2007) presented the concept of dynamic capabilities as three components-absorption, adaptation, and innovation capacities-by reconstructing the concept of dynamic capabilities. This study examined dynamic capabilities such as absorptive capacity and coordination capacity, based on the dynamic capability standards for the social innovation promotion of social enterprises presented by Vézina et al. (2019), and based on existing previous studies.

Absorptive capacity is an organization's organizational routine and process producing dynamic organizational capabilities by acquiring, assimilating, transforming, and utilizing knowledge (Zahra and George 2002; Malhotra et al. 2005). Absorptive capacity is divided into potential absorptive capacity acquiring external knowledge and assimilating, and realized absorptive capacity transforming and utilizing knowledge (Zahra and George 2002). Absorptive capacity includes an opportunity-searching process in which external knowledge is recognized and drawn inside the organization, and internalizes it as knowledge, complying with the learning process overall.

As identified in many previous studies, market orientation and technology orientation, the subconcepts of entrepreneurial strategic orientation, positively affect absorptive capacity (Na and Tian 2014). Entrepreneurial orientation is identified to positively affect absorptive capacity, such as acquiring and utilizing market information (Keh et al. 2007; Jantunen et al. 2005). Social enterprises explore business opportunities within the scope of social problems (Austin et al. 2006). Social entrepreneurs commit to looking for the demand for products and services, and creating social values with passion and innovation to develop markets (Dorado 2006). Social enterprise entrepreneurial strategic orientation factors are more likely to seize business opportunities, and can affect absorptive capacity adequately utilizing human and physical resources within an organization. This study presents the following hypotheses: 
Hypothesis 1 (H1). The social value orientation of social enterprise entrepreneurs will positively affect absorptive capacity.

Hypothesis 2 (H2). The entrepreneurial orientation of social enterprise entrepreneurs will positively affect absorptive capacity.

Hypothesis 3 (H3). The market orientation of social enterprise entrepreneurs will positively affect absorptive capacity.

Coordination capacity can promote organizational stability and growth by organizing and developing the knowledge and resources acquired through external opportunity recognition and internal learning through collaboration, teamwork, and communication. Pavlou and El Sawy (2011) defined coordination capacity as corporate activities orchestrating and developing work, resources, and organizational members' activities. Coordination capacity is a concept which dictates that collaboration, teamwork, common goal propulsion, and communication are mutually connected (Murray et al. 2011). As O'Reilly and Tushman (2004) pointed out, coordination capacity undergoes a concrete execution process of internal resource array and integration to make externally absorbed resources an organizational key capacity.

The subfactors of strategic orientation can organically work only if the capacity to integrate and coordinate various functions distributed within an organization is exerted, according to Gatignon and Xuereb (1997). Boer et al. (2006) reported that strategy and goals significantly affect coordination capacity, in that they offer not only a direction for decision-making and a motive for decision-making, but also standards for performance evaluation. Based on these previous studies, this study designed the following hypotheses:

Hypothesis 4 (H4). The social value orientation of social enterprise entrepreneurs will positively affect coordination capacity.

Hypothesis 5 (H5). The entrepreneurial orientation of social enterprise entrepreneurs will positively affect coordination capacity.

Hypothesis 6 (H6). The market orientation of social enterprise entrepreneurs will positively affect coordination capacity.

\subsection{Dynamic Capabilities and Organizational Effectiveness}

Organizational effectiveness means a specific organization's degree of goal achievement (Etzioni and Lawrence 2016). Steers (1975) defined organizational effectiveness as the capacity to actively utilize the environment to acquire scarce resources beyond the existing goal approach. The measurement of organizational effectiveness can be approached in a performance evaluation method drawn up to achieve organizational strategic goals from the four perspectives of finance, customer, internal business process, learning, and growth (Kaplan and Norton 2005). Diverse variables and measuring methods are used depending on study subjects, including earnings rate, market share, growth rate, social responsibility, product quality, leader's decision-making capability, organizational working environment style, job satisfaction, organizational commitment, and talent retention (Cameron 2010; Daft 2015).

Social enterprises can pursue organizational effectiveness and long-term growth only if they secure organizational balance and stability, as they are the organizations where social welfare logic and commercial logic co-exist. Therefore, social enterprises face problems, if organizational members change jobs and organizational effectiveness declines, when the members' commitment and job satisfaction offering social services with low wages decline (Caringal-Go and Hechanova 2018). Brown and Yoshioka (2003) pointed out that when nonprofit organizations' members' disposition is active towards the organizational mission, organizational satisfaction increases, and turnover decreases through a study of nonprofit 
organizational members' retention. The previous studies reported that organizational effectiveness could be enhanced by lowering an intention to change a job by reducing dissatisfaction with wages, as a social organization's mission orientation is stronger (Kim and Lee 2007). Likewise, job satisfaction and organizational commitment, and stability yardstick can be revealed as measuring tools centered on social organizational learning and growth.

Organizational commitment is the organizational members' commitment to making efforts for organizational development, the desire to remain, and dedication and attachment to the organization (Meyer and Allen 1991). Organizational commitment is expressed as an attitude towards the organization and attachment to organizational goals and values (Azeem 2010). Mowday et al. (2013) divided organizational commitment into attitudinal commitment and behavioral commitment, and conceptualized it. Meyer and Allen (1991) segmented organizational commitment into affective commitment, continuance commitment, and normative commitment. Members with higher organizational commitment can be closer to the goals and values of the companies, have a stronger attachment, and contribute to the company's benefits (Mowday et al. 2013). Moreover, the members' greater job performance can be drawn on (Azeem 2010). Affective commitment may have significant and positive effects on organizational citizens' behaviors and organizational performance (Meyer et al. 2002; Meyer and Allen 1991).

Aziri (2011) defined job satisfaction as the harmony of psychological and physiological situations in which organizational members are satisfied with their job. Job satisfaction refers to the emotional state of individual organizational members (Brooke et al. 1988) and an individual's affectively positive state on the job experience result (Scarpello and Vandenberg 1992). Because job satisfaction reflects expectations on the experience and results that the members carried out, the members' job participation becomes higher, and turnover becomes lower, which can positively affect organizational performance if job satisfaction increases (Spector 1997).

Dynamic capabilities affect the improvement of organizational effectiveness. According to a study by Kim et al. (2014), dynamic capabilities, as assimilation exploitation capabilities, positively affect job satisfaction, organizational commitment, and decline in intention to change job. In various previous studies (Miles et al. 2014), dynamic capabilities affect decision-making and selection to reconstitute resources within the organization, and respond to the external environment; thus, dynamic capabilities have effects on organizational effectiveness or sustainability. Based on the previous studies, this study presents the following hypotheses:

Hypothesis 7 (H7). Absorptive capacity as social enterprises' dynamic capabilities will positively affect organizational effectiveness.

Hypothesis 8 (H8). Coordination capacity as social enterprises' dynamic capabilities will positively affect organizational effectiveness.

\section{Research Method}

\subsection{Research Model}

This study examines the effects of entrepreneurial strategic orientation on organizational effectiveness, with the mediation of dynamic capabilities. Social value orientation, entrepreneurial orientation, and market orientation were set as entrepreneurial strategic orientation, an independent variable, and absorptive capacity and coordination capacity were set as dynamic capabilities, which can be a mediation variable. Lastly, organizational effectiveness, a dependent variable, consisted of organizational satisfaction and commitment. To this end, a study model was designed, as shown in Figure 1, centered on the hypotheses, based on the previous studies. 
Entrepreneurial strategic orientation

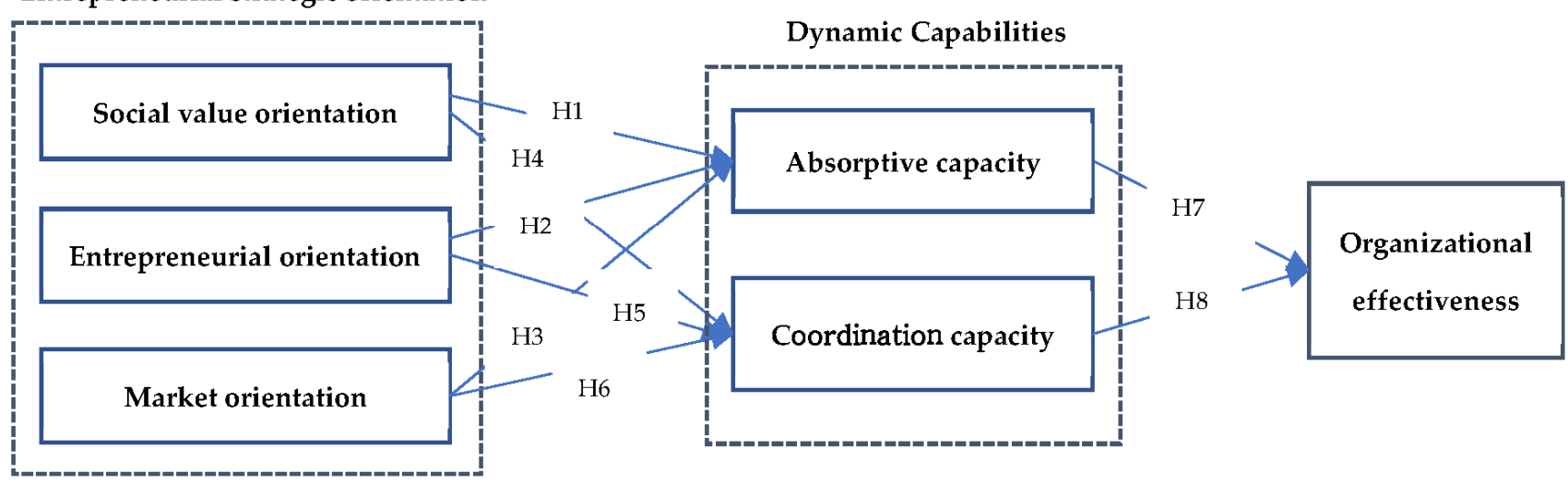

Figure 1. Research model.

\subsection{Measurement Variable and Data Collection}

A questionnaire survey was carried out for data collection to analyze the model. The questions were configured as shown in Table 1 through previous studies, and the manipulative variables of the questionnaire components were defined. When looking at the manipulative definition of the variables used for the questionnaire survey, the social value orientation factor of strategic orientation means the orientation to share the organizational mission to enhance others' welfare and public goodness, create values, and contribute to social contribution. Entrepreneurial orientation means innovativeness, proactiveness, and risk-taking to create values by pursuing market opportunities. The market orientation factor means an organization's customer orientation and competitor orientation necessary for consumers' high-value creation. Dynamic capabilities, which can be a mediation variable affected by these factors, consist of absorptive capacity and coordination capacity on business opportunities and knowledge to respond to the rapidly changing environment. Absorptive capacity means acquiring external knowledge, assimilating it within the organization, and utilizing it. Coordination capacity means a systematized process of environmental change, and an ability to respond through a cooperative attitude within the organization. Organizational effectiveness means the degree of organizational satisfaction and commitment that an organization aims and pursues.

As shown in Table 1, the variables defined as such were the questions in the questionnaire, and there were 36 questions in total. They were configured as follows: The social value orientation factor consisted of three questions related to mission sharing and three questions of value creation and social contribution, respectively, based on the previous studies of Jang and Ji (2021), Miles et al. (2013), and Sharir and Lerner (2006). The entrepreneurial orientation factor consisted of three questions of innovativeness, proactiveness, and risk-taking, respectively, based on the previous study of Covin and Denni (1989). The market orientation factor consisted of three questions of customer orientation and competitor orientation, respectively, based on the previous study of Narver and Slater (1990). Dynamic capabilities consisted of three questions of absorptive capacity and coordination capacity based on the previous studies of Pavlou and El Sawy (2011), Murray et al. (2011), and Zahra and George (2002). Organizational effectiveness consisted of three questions based on the previous studies of Vandenabeele (2009), and Wright and Cropanzano (1998). However, one out of three questions of organizational effectiveness was rejected, as a result of factor analysis and, therefore, it was analyzed with two questions. 
Table 1. Variables and measurement items.

\begin{tabular}{|c|c|c|c|c|}
\hline \multicolumn{2}{|c|}{ Factors } & \multicolumn{2}{|r|}{ Survey Items } & \multirow{2}{*}{$\begin{array}{c}\text { References } \\
\\
\text { Jang and Ji (2021), } \\
\text { Miles et al. (2013), } \\
\text { Sharir and Lerner (2006) }\end{array}$} \\
\hline \multirow{3}{*}{$\begin{array}{l}\text { Entrepreneurial } \\
\text { strategic } \\
\text { orientation }\end{array}$} & $\begin{array}{l}\text { Social value } \\
\text { orientation }\end{array}$ & $\begin{array}{l}(1) \\
(2) \\
(3)\end{array}$ & $\begin{array}{l}\text { We endeavor to provide products and services } \\
\text { required by customers (beneficiaries). } \\
\text { Our company contributes to community } \\
\text { development and stabilization. } \\
\text { Our company puts more importance on public } \\
\text { interests than individual interests. }\end{array}$ & \\
\hline & $\begin{array}{l}\text { Entrepreneurial } \\
\text { orientation }\end{array}$ & $\begin{array}{l}(2) \\
(3)\end{array}$ & $\begin{array}{l}\text { Our company endeavors to develop new and } \\
\text { innovative products and services. } \\
\text { Our company always pursues innovative change. } \\
\text { Our company professes active business } \\
\text { promotion. }\end{array}$ & $\begin{array}{c}\text { Miles et al. (2013), } \\
\text { Covin and Denni (1989) }\end{array}$ \\
\hline & $\begin{array}{c}\text { Market } \\
\text { orientation }\end{array}$ & $\begin{array}{l}\text { (2) } \\
(3)\end{array}$ & $\begin{array}{l}\text { Our company establishes strategies for a } \\
\text { competitive edge on customers' demand } \\
\text { (beneficiaries). } \\
\text { Our company identifies competitors' strategies } \\
\text { and internally shares the relevant information. } \\
\text { Our company internally discusses competitors' } \\
\text { strengths and strategies regularly. }\end{array}$ & Narver and Slater (1990) \\
\hline \multirow{2}{*}{$\begin{array}{c}\text { Dynamic } \\
\text { capabilities }\end{array}$} & $\begin{array}{l}\text { Absorptive } \\
\text { capacity }\end{array}$ & $\begin{array}{l}(1) \\
(2) \\
(3)\end{array}$ & $\begin{array}{l}\text { Our company is good at utilizing staffing by } \\
\text { employing experienced employees in other fields. } \\
\text { Our company can benchmark other companies' } \\
\text { merits and properly combine and utilize them. } \\
\text { Our company has an excellent ability to overcome } \\
\text { crises and continuously responds to crises well. }\end{array}$ & \multirow{2}{*}{$\begin{array}{c}\text { Pavlou and El Sawy (2011), } \\
\text { Murray et al. (2011), } \\
\text { Zahra and George (2002) }\end{array}$} \\
\hline & $\begin{array}{l}\text { Coordination } \\
\text { capacity }\end{array}$ & $\begin{array}{l}\text { (2) } \\
(3)\end{array}$ & $\begin{array}{l}\text { In our company, processes are well-connected } \\
\text { between departments to propel our common } \\
\text { goals. } \\
\text { Our company members mutually cooperate } \\
\text { reasonably. } \\
\text { Our company solves problems through adequate } \\
\text { conversations and joint efforts. }\end{array}$ & \\
\hline \multicolumn{2}{|c|}{ Organizational effectiveness } & $\begin{array}{l}(1) \\
(2) \\
(3)\end{array}$ & $\begin{array}{l}\text { I feel rewarded for and satisfied with the current } \\
\text { duties } \\
\text { Our company members feel delighted through } \\
\text { their work. } \\
\text { Our company members will allocate their private } \\
\text { time to work. }\end{array}$ & $\begin{array}{l}\text { Vandenabeele (2009), Wright } \\
\text { and Cropanzano (1998) }\end{array}$ \\
\hline
\end{tabular}

\subsection{Demographic Information of the Data}

This study carried out an online questionnaire survey through random samples targeting employees working at social enterprises certified by the Korean Ministry of Employment and Labor. The questionnaire survey was carried out for 36 days between 15 August 2021, and 20 September 2021. Two hundred and forty-one copies of the questionnaire responses were collected, and 228 copies were analyzed, except four insincere responses.

As shown in Table 2, for the gender of the respondents, males represent $53.5 \%$, and females represent $46.5 \%$. Concerning age, $3.5 \%$ were younger than $30,21.1 \%$ were from $30-40,31.7 \%$ were $40-50$, and $44.7 \%$ were 50 or over. Regarding career, $7.0 \%$ had been working for less than one year, $14.0 \%$ had been working for one to less than two years, $16.7 \%$ had been working for three to less than five years, $27.6 \%$ had been working for 5 to less than 10 years, $15.4 \%$ had been working for 10 to less than 15 years, and $19.3 \%$ had been working 
for 15 years or more. As for position, employee, deputy section chief, middle manager, and executive had $11.4 \%, 8.3 \%, 25 \%$, and $55.3 \%$, each. For organizational type, the job offer registered as $58.3 \%$, taking up more than half of the total respondents; social service offer was $11.0 \%$, mixed type $7.5 \%$, community contribution was $11.0 \%$, and others (creative, innovative) were $12.3 \%$. Concerning the company's size, 10 or fewer employees took up $49.6 \%, 11-20$ employees-21.1\%, 21-50 employees- $16.2 \%$, 51-100 employees-3.1\%, and over 100 employees-10.1\%.

Table 2. Demographic information of survey participants.

\begin{tabular}{|c|c|c|c|}
\hline \multicolumn{2}{|c|}{ Category } & \multirow{2}{*}{$\frac{\text { Frequency }}{122}$} & \multirow{2}{*}{$\begin{array}{c}\text { Percentage } \\
53.5\end{array}$} \\
\hline & Male & & \\
\hline Gender & Female & 106 & 46.5 \\
\hline & Total & 228 & 100.0 \\
\hline \multirow{5}{*}{ Age } & Younger than 30 & 8 & 3.5 \\
\hline & 30 to 40 & 48 & 21.1 \\
\hline & 40 to 50 & 70 & 30.7 \\
\hline & 50 or over & 102 & 44.7 \\
\hline & Total & 228 & 100.0 \\
\hline \multirow{7}{*}{ Career (years) } & 1 or less & 16 & 7.0 \\
\hline & 1 to less than 2 & 32 & 14.0 \\
\hline & 3 to less than 5 & 38 & 16.7 \\
\hline & 5 to less than 10 & 63 & 27.6 \\
\hline & 10 to less than 15 & 35 & 15.4 \\
\hline & 15 or more & 44 & 19.3 \\
\hline & Total & 228 & 100.0 \\
\hline \multirow{5}{*}{ Position } & Employee & 26 & 11.4 \\
\hline & Deputy Section Chief & 19 & 8.3 \\
\hline & Middle Manager & 57 & 25.0 \\
\hline & Executive & 126 & 55.3 \\
\hline & Total & 228 & 100.0 \\
\hline \multirow{6}{*}{ Organizational type } & Job offer & 133 & 58.3 \\
\hline & Social service offer & 25 & 11.0 \\
\hline & Mixed & 17 & 7.5 \\
\hline & $\begin{array}{l}\text { Community } \\
\text { contribution }\end{array}$ & 25 & 11.0 \\
\hline & $\begin{array}{l}\text { Others (creative, } \\
\text { innovative) }\end{array}$ & 28 & 12.3 \\
\hline & Total & 228 & 100.0 \\
\hline \multirow{6}{*}{$\begin{array}{l}\text { Size of company } \\
\text { (employees) }\end{array}$} & 10 or less & 113 & 49.6 \\
\hline & $11-20$ & 48 & 21.1 \\
\hline & $21-50$ & 37 & 16.2 \\
\hline & 51-100 & 7 & 3.1 \\
\hline & Over 100 & 23 & 10.1 \\
\hline & Total & 228 & 100.0 \\
\hline
\end{tabular}

\section{Results}

\subsection{Analysis Results of Reliability and Validity}

The analysis results of reliability and convergent validity of the measurement model were all good, as shown in Table 3. Internal consistency reliability was verified based on a composite reliability index of 0.7 or higher of the structural equation measurement model. Validation was verified through standardized factor loading, Cronbach's $\alpha$, and composite reliability index values in terms of convergent validity. In line with the standards, the standardized factor loading was good at 0.662 to 0.889 , and internal reliability was between 0.714 to 0.901 , so significance was secured. Because the $t$ value was 8.0 or more, it was confirmed to be statistically significant. The average variance extracted (AVE) value was 
from 0.530 to 0.752 , and Cronbach's $\alpha$ was 0.770 to 0.898 ; therefore, convergent validity was secured. As a result of analyzing the goodness-of-fit of the measurement model, $\chi^{2}(\mathrm{df})$ was 336.153 , and $\chi^{2}$ /degree of freedom was 2.169. Goodness-of-Fit-Index (GFI) value was 0.876, Adjusted Goodness-of-Fit-Index (AGFI) was 0.831, Normal Fit Index (NFI) was 0.885, and Root Mean Square Error of Approximation (RMSEA) was 0.072. Therefore, the constructed values of the goodness-of-fit of the measurement model were statistically very significant.

Table 3. Results of reliability and convergent validity test.

\begin{tabular}{|c|c|c|c|c|c|c|c|}
\hline \multicolumn{2}{|c|}{ Variable } & \multirow{2}{*}{$\begin{array}{c}\begin{array}{c}\text { Standard Factor } \\
\text { Loading }\end{array} \\
0.804\end{array}$} & \multirow[t]{2}{*}{$\begin{array}{c}\text { Standard } \\
\text { Deviation }\end{array}$} & \multirow[t]{2}{*}{ t Value (p) } & \multirow[t]{2}{*}{ CR } & \multirow[t]{2}{*}{ AVE } & \multirow[t]{2}{*}{$\begin{array}{c}\text { Cronbach's } \\
\alpha\end{array}$} \\
\hline \multirow{3}{*}{$\begin{array}{l}\text { Social value } \\
\text { orientation }\end{array}$} & SV_1 & & & & & & \\
\hline & SV_2 & 0.763 & 0.089 & $11.195^{* * *}$ & \multirow[t]{2}{*}{0.821} & \multirow[t]{2}{*}{0.605} & \multirow[t]{2}{*}{0.819} \\
\hline & SV_3 & 0.765 & 0.086 & $11.228^{* * *}$ & & & \\
\hline \multirow{3}{*}{$\begin{array}{c}\text { Entrepreneurial } \\
\text { orientation }\end{array}$} & EO_1 & 0.807 & & & \multirow{3}{*}{0.891} & \multirow{3}{*}{0.622} & \multirow{3}{*}{0.889} \\
\hline & EO_2 & 0.723 & 0.090 & $11.763^{* * *}$ & & & \\
\hline & EO_3 & 0.881 & 0.082 & $15.213^{* * *}$ & & & \\
\hline \multirow{3}{*}{$\begin{array}{c}\text { Market } \\
\text { orientation }\end{array}$} & MO_1 & 0.676 & & & \multirow{3}{*}{0.859} & \multirow{3}{*}{0.605} & \multirow{3}{*}{0.855} \\
\hline & MO_2 & 0.788 & 0.122 & $10.400^{* * *}$ & & & \\
\hline & MO_3 & 0.810 & 0.125 & $10.636^{* * *}$ & & & \\
\hline \multirow{3}{*}{$\begin{array}{c}\text { Absorptive } \\
\text { capacity }\end{array}$} & AC_1 & 0.662 & & & \multirow{3}{*}{0.771} & \multirow{3}{*}{0.530} & \multirow{3}{*}{0.770} \\
\hline & AC_2 & 0.758 & 0.100 & $9.592 * * *$ & & & \\
\hline & AC_3 & 0.760 & 0.099 & $9.606^{* * *}$ & & & \\
\hline \multirow{3}{*}{$\begin{array}{l}\text { Coordination } \\
\text { capacity }\end{array}$} & CC_1 & 0.840 & & & \multirow{3}{*}{0.901} & \multirow{3}{*}{0.752} & \multirow{3}{*}{0.898} \\
\hline & CC_2 & 0.871 & 0.059 & $16.132^{* * *}$ & & & \\
\hline & CC_3 & 0.889 & 0.057 & $16.584^{* * *}$ & & & \\
\hline \multirow{2}{*}{$\begin{array}{c}\text { Organizational } \\
\text { effectiveness }\end{array}$} & OE_1 & 0.730 & & & \multirow{2}{*}{0.714} & \multirow{2}{*}{0.555} & \multirow{2}{*}{0.714} \\
\hline & OE_2 & 0.760 & 0.103 & $8.447^{* * *}$ & & & \\
\hline
\end{tabular}

Measurement model fit: $\chi^{2}$ (df) 336.153, $\chi^{2}$ /degree of freedom 2.169, RMR 0.044, GFI 0.876, AGFI 0.831, NFI 0.885, TLI 0.918, CFI 0.933, RMSEA 0.072/Note: ${ }^{* * *} p<0.001$.

As a result of analyzing the AVE value and CR value between potential variables in this study, the AVE square root of each potential value was more prominent than coefficients between potential variables, as shown in Table 4. From this, it was confirmed that discrimination validity was secured.

Table 4. Discriminant validity.

\begin{tabular}{cccccccc}
\hline Category & AVE & SV & EO & MO & AC & CC & OE \\
\hline Social value orientation (SV) & 0.605 & $\mathbf{0 . 7 7 8}$ & & & & & \\
Entrepreneurial orientation (EO) & 0.622 & 0.566 & $\mathbf{0 . 7 8 9}$ & & & & \\
Market orientation (MO) & 0.605 & 0.491 & 0.610 & $\mathbf{0 . 7 7 8}$ & & \\
Absorptive capacity (AC) & 0.530 & 0.429 & 0.579 & 0.668 & $\mathbf{0 . 7 2 8}$ & \\
Coordination capacity (CC) & 0.752 & 0.492 & 0.551 & 0.602 & 0.649 & $\mathbf{0 . 8 6 7}$ & \\
Organizational effectiveness (OE) & 0.555 & 0.413 & 0.402 & 0.505 & 0.439 & 0.541 & $\mathbf{0 . 7 4 5}$ \\
\hline
\end{tabular}

The square root of AVE is shown in bold letters.

\subsection{Analysis Results of Structural Model}

According to the structural model's goodness-of-fit analysis result, as presented in Table $5, \chi^{2}(\mathrm{p})$ was 364.024 , and $\chi^{2} /$ degree of freedom was 2.289 . GFI was 0.868 , NFI was 0.875 , AGFI was 0.826, RMR was 0.047, and RMSEA was 0.075; therefore, the constructed values were significant. Although not affected by the samples, the CFI indicating the model's explanation power was 0.925, and the TLI judging the structural model's power of explanation was 0.910 . All were over 0.9 , so the primary model was analyzed to be appropriate. 
As a result of hypotheses verification through the path analysis of the structural equation model's path, as shown in Table 5, two hypotheses were rejected among eight hypotheses in total. Among the entrepreneurial strategic orientation factors of social enterprises, the entrepreneurial orientation $(2.389, p<0.05)$ and market orientation $(6.345$, $p<0.001)$ positively affected absorptive capacity. However, the social value orientation hypothesis was rejected, so it did not have an effect. Meanwhile, social value orientation $(2.520, p<0.05)$ and market orientation $(5.057, p<0.001)$ positively affected coordination capacity. Both absorptive capacity $(2.659 p<0.001)$ and coordination capacity $(4.778$, $p<0.001)$ positively affected organizational effectiveness; therefore, the hypotheses were adopted.

Table 5. Results of hypothesis test.

\begin{tabular}{|c|c|c|c|c|c|}
\hline & Hypothesis (Path) & $\begin{array}{l}\text { Standard Path } \\
\text { Coefficient }\end{array}$ & t Value & $\begin{array}{l}\text { Status of } \\
\text { Adoption }\end{array}$ & $\mathbf{R}^{2}$ \\
\hline $\mathrm{H} 1$ & Social value orientation $->$ Absorptive capacity & 0.036 & 0.432 & Rejected & \multirow{3}{*}{0.549} \\
\hline $\mathrm{H} 2$ & Entrepreneurial orientation $->$ Absorptive capacity & 0.224 & $2.389 *$ & Adopted & \\
\hline $\mathrm{H} 3$ & Market orientation $->$ Absorptive capacity & 0.692 & $6.345^{* * *}$ & Adopted & \\
\hline $\mathrm{H} 4$ & Social value orientation -> Coordination capacity & 0.216 & $2.520 *$ & Adopted & \multirow{3}{*}{0.777} \\
\hline H5 & Entrepreneurial orientation $->$ Coordination capacity & 0.165 & 1.768 & Rejected & \\
\hline H6 & Market orientation $->$ Coordination capacity & 0.463 & $5.057^{* * *}$ & Adopted & \\
\hline H7 & Absorptive capacity -> Organizational effectiveness & 0.277 & $2.659 * *$ & Adopted & \multirow[b]{2}{*}{0.507} \\
\hline $\mathrm{H} 8$ & Coordination capacity $->$ Organizational effectiveness & 0.502 & $4.778^{* * *}$ & Adopted & \\
\hline
\end{tabular}

Structural model fit: $\chi^{2}(\mathrm{df}) 364.024, \chi^{2} /$ degree of freedom 2.289, RMR 0.047, GFI 0.868, AGFI 0.826, NFI 0.875, TLI 0.910 , CFI 0.925, RMSEA 0.075. Note: ${ }^{*} p<0.05,{ }^{* *} p<0.01,{ }^{* * *} p<0.001$.

\subsection{Analysis Results of Mediated Effect}

As examined through Table 6, this study drew direct, indirect, and total effects using Sobel test techniques to verify the significance of indirect effects. Like the path analysis result above, absorption capacity was revealed not to mediate all the orientation factors and organizational effectiveness, and coordination capacity was confirmed to mediate the orientation factors and organizational effectiveness. It was confirmed that market orientation affected organizational effectiveness through the mediation of coordination capacity $(0.108, p<0.05)$. Social value orientation $(0.083, p<0.01)$ affected organizational effectiveness with the mediation of coordination capacity, and entrepreneurial orientation $(0.232, p<0.001)$ affected organizational effectiveness through the mediation of coordination capacity.

Table 6. Results of mediated effect.

\begin{tabular}{ccccc}
\hline Dependent Variable & Explanatory Variable & Direct Effect & Indirect Effect & Total Effect \\
\hline & Absorptive capacity & 0.277 & - & 0.227 \\
& Social value orientation & - & 0.010 & 0.010 \\
& Entrepreneurial orientation & - & 0.062 & 0.062 \\
Organizational & Market orientation & - & 0.192 & 0.192 \\
\cline { 2 - 5 } effectiveness & Coordination capacity & 0.502 & - & 0.502 \\
& Social value orientation & - & $0.108^{*}$ & 0.108 \\
& Entrepreneurial orientation & - & $0.083^{* *}$ & 0.083 \\
& Market orientation & - & $0.232^{* * *}$ & 0.232 \\
\hline
\end{tabular}

Note: ${ }^{*} p<0.05,{ }^{* *} p<0.01,{ }^{* * *} p<0.001$.

\section{Discussion}

This study empirically analyzed the effect of the strategic orientation of social enterprises on organizational effectiveness with the mediation of dynamic capabilities. According to the study results, entrepreneurial orientation and market orientation in the strategic 
orientation of social enterprises positively affected absorptive capacity. The factors positively affecting coordination capacity were social value orientation and market orientation. It was deduced that the core factor affecting both absorptive capacity and coordination capacity and mediating organizational effectiveness was the market orientation factor. It was revealed that entrepreneurial orientation and social value orientation affected organizational effectiveness with the mediation of absorptive capacity and coordination capacity, respectively.

Therefore, differences in characteristics and effectiveness were demonstrated depending on orientation type. Consequently, this study produced the following implications:

First, market orientation affected organizational effectiveness the most in strategic orientation. Market orientation significantly affected absorptive capacity, quickly recognizing market opportunity and assimilating it within the organization and coordination capacity, readjusting obtained resources to be suitable for organizational features. Social enterprises can be enhanced the market competitiveness by quickly identifying what needs to change with the product and service beneficiaries, and maintaining a close relationship with major stakeholders like government and charity organizations. Like the previous studies' result indicating that profit-making enterprises need entrepreneurial market orientation (Nicholls and Cho 2006; Bhattarai et al. 2019; Morris et al. 2007), it was confirmed that more effective organizational activities and performance could be obtained if market orientation is equipped to recognize welfare beneficiaries' needs, and propose new service values.

Second, absorptive capacity was not used, as the meditation of social value orientation, entrepreneurial orientation and market orientation affects organizational effectiveness. Zahra and George (2002) classified absorption capacity as knowledge utilization, which means how deeply members reuse existing knowledge, and knowledge exploration, which means how widely they acquire and accept new knowledge. Duchek (2013) argued that there are differences in absorption capacity, but that it ultimately understands and adapts to rapidly changing IT environments. From a short-term perspective, the use of existing internal knowledge has a cost advantage in terms of time and cost over the search for knowledge to acquire and develop new external resources. However, the results of this study show that, in the case of social enterprises, it is more important to selectively acquire knowledge exploration and knowledge utilization and strategize based on internal coordination than to combine the diversity of external knowledge exploration and applicability of internal knowledge utilization. In the case of social enterprises, unlike general enterprises, they have lower sensitivity to the external environment, and it shows that focusing on strengthening various internal capabilities may be more advantageous in terms of organizational effectiveness.

Third, in consideration of the market characteristics, more significant effects can be exerted if entrepreneurial orientation, such as the entrepreneur's innovativeness and proactiveness, is manifested as coordination capacity, attracting external resources and assimilating them internally. Social enterprises are unfavorable compared to market entry compared to general profit-making companies, in that they need to find niche markets with social needs, due to government failures and market failures (Phillips 2006; Hynes 2009). It was confirmed that organizational effectiveness could be revealed if coordination capacity, which suitably and stably adjusts social value-centered vision and strategic orientation pursued by organizations and entrepreneurs and minimizes conflicts, is backed up.

\section{Conclusions}

Consequently, this study presents the following implications based on the results of this study: From an academic aspect, this study presents a result that absorptive capacity and coordination capacity, which are social enterprises' dynamic capabilities, positively affect organizational effectiveness. Generally, social enterprises lack the consideration of dynamic capabilities or organizational effectiveness, depending on the characteristics of organizations pursuing social values and performing nonprofit management activities. However, social enterprises must adapt to the new environment and secure new business 
competitiveness, like general profit-making enterprises within the rapidly changing and uncertain social environment. In consideration of the changed socioeconomic paradigm, this study shows significant implications from an aspect that social enterprises' strategies, orientation, and effectiveness were examined in consideration of the changed socioeconomic paradigm. Specifically, this study presents the importance of dynamic capabilities.

When looking at a practical aspect, entrepreneurs operating social enterprises are requested to make difficult decisions to simultaneously pursue economic and social values, and judge conflict problems between the two values in a balanced way. From this aspect, standards affecting priority and strategic orientation decision-making, such as social values, entrepreneurial spirit, and the market are needed. This study implies that market orientation can be prioritized in social entrepreneurs' rational and objective decisions on management sites. Flexible management activities through which social enterprises can be operated by differentiating organizational capacity types are necessary depending on strategic goals.

Like general venture businesses, social enterprises should indulge a passion for overcoming the liability of newness and liability of smallness, and for obtaining new business opportunities and securing resources. In this context, there is a need to strengthen strategic goals and dynamic capabilities through which social enterprises can flexibly cope with the business and economic environment beyond nonprofit and value organization orientation. The entrepreneurs of social enterprises should exert more innovative and proactive business leadership by reinforcing the absorptive capacity of internal and external environments and resources for entrepreneurial spirit manifestation.

This study has a limitation in that it was use the research data collected only by Korean social enterprises.In a further study, research targeting social enterprises by continents and countries should be carried out, and a more generalized empirical study needs to be performed. This study dealt with social value, entrepreneurial spirit, and market orientation as the strategic orientation factors of social entrepreneurs based on previous strategic orientation studies. However, there is a need to define components of strategic orientation based on the unique characteristics of entrepreneurs of social enterprises. In a further study, the discovery of social entrepreneurs' strategic orientation components should be carried out through qualitative research techniques, such as grounded theory or the Delphi technique, based on which, an empirical study on effectiveness is necessary.

This study has a limitation in that it was performed not taking into account various economic type features, although diverse economic types exist, including cooperative associations and social enterprises. In the future, empirical studies and studies on comparative analysis by type considering various types of organizations pursuing social values and economic values simultaneously can be carried out.

Author Contributions: Conceptualization, C.C.; methodology, C.C.; software, S.O.; validation, C.C. and B.K..; formal analysis, S.O.; investigation, C.C.; resources, C.C.; data curation, S.O.; writingoriginal draft preparation, C.C. and B.K.; writing-review and editing, B.K.; visualization, B.K.; supervision, B.K.; project administration, B.K.; funding acquisition, C.C. All authors have read and agreed to the published version of the manuscript.

Funding: This research received no external funding.

Institutional Review Board Statement: "Not applicable" for studies not involving humans or animals.

Informed Consent Statement: Informed consent was obtained from all subjects involved in the study.

Data Availability Statement: Data are not publicly available due to the privacy of respondents.

Conflicts of Interest: The authors declare no conflict of interest. 


\section{References}

Alter, Kim. 2007. Social enterprise typology. Virtue Ventures LLC 12: 1-124.

Austin, James, Howard Stevenson, and Jane Wei-Skillern. 2006. Social and commercial entrepreneurship: Same, different, or both? Entrepreneurship Theory and Practice 30: 1-22. [CrossRef]

Azeem, Syed Mohammad. 2010. Job satisfaction and organizational commitment among employees in the Sultanate of Oman. Psychology 1: 295-300. [CrossRef]

Aziri, Brikend. 2011. Job satisfaction: A literature review. Management Research E Practice 3: 77-86.

Barney, Jay. 1991. Firm resources and sustained competitive advantage. Journal of management 17: 99-120. [CrossRef]

Battilana, Julie, and Silvia Dorado. 2010. Building sustainable hybrid organizations: The case of commercial microfinance organizations. Academy of Management Journal 53: 1419-40. [CrossRef]

Besharov, Marya L., and Wendy K. Smith. 2012. Multiple Logics within Organizations: An Integrative Framework and Model of Organizational Hybridity. Ithaca: Cornell University Working Paper.

Bhattarai, Charan Raj, Caleb C. Y. Kwong, and Misagh Tasavori. 2019. Market orientation, market disruptiveness capability and social enterprise performance: An empirical study from the United Kingdom. Journal of Business Research 96: 47-60. [CrossRef]

Boehm, Amnon, Eran Vigoda-Gadot, and Nurit Segev. 2011. Market orientation in social services: An empirical study of motivating and hindering factors among Israeli social workers. Administration in Social Work 35: 138-60. [CrossRef]

Boer, Harry, Joachim Kuhn, and Frank Gertsen. 2006. Continuous Innovation: Managing Dualities through Co-ordination. CINet Working Paper Series, WP2006-01. Available online: http://www.continuous-innovation.net/Publications/CINet)Publications.html (accessed on 16 November 2021).

Brooke, Paul P., Daniel W. Russell, and James L. Price. 1988. Discriminant validation of measures of job satisfaction, job involvement, and organizational commitment. Journal of Applied Psychology 73: 139-45. [CrossRef]

Brown, William A., and Carlton F. Yoshioka. 2003. Mission attachment and satisfaction as factors in employee retention. Nonprofit Management and Leadership 14: 5-18. [CrossRef]

Bull, Mike, and Rory Ridley-Duff. 2019. Towards an appreciation of ethics in social enterprise business models. Journal of Business Ethics 159: 619-34. [CrossRef]

Cameron, Kim. 2010. Five keys to flourishing in trying times. Leader to Leader 55: 45-51. [CrossRef]

Caringal-Go, Jaimee Felice, and Ma Regina M. Hechanova. 2018. Motivational needs and intent to stay of social enterprise workers. Journal of Social Entrepreneurship 9: 200-14. [CrossRef]

Covin, Jeffrey, and Slevin Denni. 1989. Strategic management of small firms in hostile and benign environments. Strategic management journal 10: 75-87. [CrossRef]

Daft, Richard L. 2015. Organization Theory and Design. Boston: Cengage Learning.

Defourny, Jacques, and Marthe Nyssens. 2010. Conceptions of social enterprise and social entrepreneurship in Europe and the United States: Convergences and divergences. Journal of Social Entrepreneurship 1: 32-53. [CrossRef]

Defourny, Jacques, Marthe Nyssens, and Olivier Brolis. 2021. Testing social enterprise models across the world: Evidence from the international comparative social enterprise models (ICSEM) project. Nonprofit and Voluntary Sector Quarterly 50: 420-40. [CrossRef]

Doherty, Bob, Helen Haugh, and Fergus Lyon. 2014. Social enterprises as hybrid organizations: A review and research agenda. International Journal of Management Reviews 16: 417-36. [CrossRef]

Dorado, Silvia. 2006. Social entrepreneurial ventures: Different values so different process of creation, no? Journal of Developmental Entrepreneurship 11: 319-43. [CrossRef]

Duchek, Stephanie. 2013. Capturing absorptive capacity: A critical review and future prospects. Schmalenbach Business Review 65: 312-29. [CrossRef]

Dwivedi, Abhishek, and Jay Weerawardena. 2018. Conceptualizing and operationalizing the social entrepreneurship construct. Journal of Business Research 86: 32-40. [CrossRef]

Eisenhardt, Kathleen M., and Jeffrey A. Martin. 2000. Dynamic capabilities: What are they? Strategic Management Journal 21: 1105-21. [CrossRef]

Etzioni, Amitai, and Paul R. Lawrence. 2016. Socio-Economics: Toward a New Synthesis. London: Routledge.

Gatignon, Hubert, and Jean-Marc Xuereb. 1997. Strategic orientation of the firm and new product performance. Journal of Marketing Research 34: 77-90. [CrossRef]

Grassl, Wolfgang. 2012. Business models of social enterprise: A design approach to hybridity. ACRN Journal of Entrepreneurship Perspectives 1: 37-60.

Hult, G. Tomas M., Charles C. Snow, and Destan Kandemir. 2003. The role of entrepreneurship in building cultural competitiveness in different organizational types. Journal of Management 29: 401-26. [CrossRef]

Hynes, Briga. 2009. Growing the social enterprise-issues and challenges. Social Enterprise Journal 5: 114-25. [CrossRef]

Jang, Hyun-Suk, and Eun-Gu Ji. 2021. A study of validity and development of the social value orientation scale of social enterprises. Social Economy \& Policy Studies 11: 37-67.

Jantunen, Ari, Kaisu Puumalainen, Sami Saarenketo, and Kalevi Kyläheiko. 2005. Entrepreneurial orientation, dynamic capabilities and international performance. Journal of International Entrepreneurship 3: 223-43. [CrossRef]

Jeong, Insik, Jae H. Pae, and Dongsheng Zhou. 2006. Antecedents and consequences of the strategic orientations in new product development: The case of Chinese manufacturers. Industrial Marketing Management 35: 348-58. [CrossRef] 
Kaplan, Robert S., and David P. Norton. 2005. The balanced scorecard: Measures that drive performance. Harvard Business Review 83: 71-79.

Keh, Hean Tat, Thi Tuyet Mai Nguyen, and Hwei Ping Ng. 2007. The effects of entrepreneurial orientation and marketing information on the performance of SMEs. Journal of Business Venturing 22: 592-611. [CrossRef]

Kerlin, Janelle A. 2006. Social enterprise in the United States and Europe: Understanding and learning from the differences. Voluntas: International Journal of Voluntary and Nonprofit Organizations 17: 246. [CrossRef]

Kim, Seok-Eun, and Jung-Wook Lee. 2007. Is mission attachment an effective management tool for employee retention? An empirical analysis of a nonprofit human services agency. Review of Public Personnel Administration 27: 227-48.

Kim, Soo-Young, Wang-Jin Yoo, and Sang-Jin Lee. 2014. An improvement of organizational effectiveness through the analysis of the relationship between entrepreneurship and dynamic capabilities in IT venture business. Journal of Society for e-Business Studies 19: 101-17. [CrossRef]

Kohli, Ajay K., and Bernard J. Jaworski. 1990. Market orientation: The construct, research propositions, and managerial implications. Journal of Marketing 54: 1-18. [CrossRef]

Korea Social Enterprise Promotion Agency. 2021. Korea Social Economy. Seoul: KEPA.

Liu, Gordon, Sachiko Takeda, and Wai-Wai Ko. 2014. Strategic orientation and social enterprise performance. Nonprofit and Voluntary Sector Quarterly 43: 480-501. [CrossRef]

Lumpkin, G. Tom, and Gregory G. Dess. 1996. Clarifying the entrepreneurial orientation construct and linking it to performance. Academy of Management Review 21: 135-72. [CrossRef]

Malhotra, Arvind, Sanjay Gosain, and Omar A. El Sawy. 2005. Absorptive capacity configurations in supply chains: Gearing for partner-enabled market knowledge creation. MIS Quarterly 29: 145-87. [CrossRef]

Meyer, John P., and Natalie J. Allen. 1991. A three-component conceptualization of organizational commitment. Human Resource Management Review 1: 61-89. [CrossRef]

Meyer, John P., David J. Stanley, Lynne Herscovitch, and Laryssa Topolnytsky. 2002. Affective, continuance, and normative commitment to the organization: A meta-analysis of antecedents, correlates, and consequences. Journal of Vocational Behavior 61: 20-52. [CrossRef]

Miles, Morgan P., Martie-Louise Verreynne, and Belinda Luke. 2014. Social enterprises and the performance advantages of a Vincentian marketing orientation. Journal of Business Ethics 123: 549-56. [CrossRef]

Miles, Morgan P., Martie-Louise Verreynne, Belinda Luke, Roy Eversole, and Josephine Barracket. 2013. The relationship of entrepreneurial orientation, Vincentian values and economic and social performance in social enterprise. Review of Business 33 : 91-102.

Miller, Danny. 1983. The correlates of entrepreneurship in three types of firms. Management Science 29: 770-91. [CrossRef]

Morris, Michael H., Justin W. Webb, and Rebecca J. Franklin. 2011. Understanding the manifestation of entrepreneurial orientation in the nonprofit context. Entrepreneurship Theory and Practice 35: 947-71. [CrossRef]

Morris, Michael H., Susan Coombes, Minet Schindehutte, and Jeffrey Allen. 2007. Antecedents and outcomes of entrepreneurial and market orientations in a non-profit context: Theoretical and empirical insights. Journal of Leadership E Organizational Studies 13: 12-39.

Mowday, Richard T., Lyman W. Porter, and Richard M. Steers. 2013. Employee-Organization Linkages: The Psychology of Commitment, Absenteeism, and Turnover. Cambridge: Academic Press.

Murray, Janet Y., Gerald Yong Gao, and Masaaki Kotabe. 2011. Market orientation and performance of export ventures: The process through marketing capabilities and competitive advantages. Journal of the Academy of Marketing Science 39: 252-69. [CrossRef]

$\mathrm{Na}$, Sang-Gyun, and Chen Tian. 2014. A Study on the Effects of Market and Technological Orientation of Manufacturing Companies upon Absorptive Capacities and Product Development Performance. Journal of the Korea Safety Management and Science 16: 263-74. [CrossRef]

Narver, John C., and Stanley F. Slater. 1990. The effect of a market orientation on business profitability. Journal of marketing 54: 20-35. [CrossRef]

Nicholls, Alex, and Albert Hyunbae Cho. 2006. Social Entrepreneurship: The Structuration of a Field. Social Entrepreneurship: New Models of Sustainable Social Change. Oxford: Oxford University Press.

O'Reilly, Charles A., and Michael L. Tushman. 2004. The ambidextrous organization. Harvard Business Review 82: 74-83.

Oliver, Christine. 1991. Strategic responses to institutional processes. Academy of Management Review 16: 145-79. [CrossRef]

Pache, Anne-Claire, and Filipe Santos. 2013. Inside the hybrid organization: Selective coupling as a response to competing institutional logics. Academy of Management Journal 56: 972-1001. [CrossRef]

Pavlou, Paul A., and Omar A. El Sawy. 2011. Understanding the elusive black box of dynamic capabilities. Decision Sciences 42: $239-73$. [CrossRef]

Phillips, Mary. 2006. Growing pains: The sustainability of social enterprises. The International Journal of Entrepreneurship and Innovation 7: 221-30. [CrossRef]

Prasetyo, Aries Heru, and Kim-Fatt Khiew. 2016. The Dynamic Capabilities of Social Enterprise: Explicating the Role of Antecedents and Unobserved Linkage. European Journal of Business and Management 8: 401-12.

Santos, Filipe M. 2012. A positive theory of social entrepreneurship. Journal of Business Ethics 111: 335-51. [CrossRef] 
Scarpello, Vida, and Robert J. Vandenberg. 1992. Generalizing the importance of occupational and career views to job satisfaction attitudes. Journal of Organizational Behavior 13: 125-40. [CrossRef]

Sharir, Moshe, and Miri Lerner. 2006. Gauging the success of social ventures initiated by individual social entrepreneurs. Journal of World Business 41: 6-20. [CrossRef]

Slater, Stanley F., and John C. Narver. 1995. Market orientation and the learning organization. Journal of Marketing 59: 63-74. [CrossRef]

Slater, Stanley F., and John C. Narver. 2000. The positive effect of a market orientation on business profitability: A balanced replication. Journal of Business Research 48: 69-73. [CrossRef]

Soh, Jung-In. 2012. The Dynamics and Long-Term Stability of Social Enterprise: Patterns in Social Entrepreneurship Research. Northhampton: Edward Elgar Publishing.

Spector, Paul E. 1997. Job Satisfaction: Application, Assessment, Causes, and Consequences. New York: Sage Publication.

Steers, Richard M. 1975. Problems in the measurement of organizational effectiveness. Administrative Science Quarterly 20: 546-58. [CrossRef]

Teece, David J. 2007. Explicating dynamic capabilities: The nature and microfoundations of (sustainable) enterprise performance. Strategic Management Journal 28: 1319-50. [CrossRef]

Teece, David J., Gary Pisano, and Amy Shuen. 1997. Dynamic capabilities and strategic management. Strategic Management Journal 18: 509-33. [CrossRef]

Vandenabeele, Wouter. 2009. The mediating effect of job satisfaction and organizational commitment on self-reported performance: More robust evidence of the PSM-Performance relationship. International Review of Administrative Sciences 75: 11-34. [CrossRef]

Vézina, Martine, Majdi Ben Selma, and Marie Claire Malo. 2019. Exploring the social innovation process in a large market based social enterprise: A dynamic capabilities approach. Management Decision 57: 1399-414. [CrossRef]

Vittoria, M. Patrizia, and Pasquale Persico. 2010. Social Enterprise in Dynamic Capabilities Management Model. Naples: Stern School of Business.

Wang, Catherine L., and Pervaiz K. Ahmed. 2007. Dynamic capabilities: A review and research agenda. International Journal of Management Reviews 9: 31-51. [CrossRef]

Weerawardena, Jay, and Gillian Sullivan Mort. 2006. Investigating social entrepreneurship: A multidimensional model. Journal of World Business 41: 21-35. [CrossRef]

Wiklund, Johan, and Dean Shepherd. 2003. Knowledge-based resources, entrepreneurial orientation, and the performance of small and medium-sized businesses. Strategic Management Journal 24: 1307-14. [CrossRef]

Wright, Thomas A., and Russell Cropanzano. 1998. Emotional exhaustion as a predictor of job performance and voluntary turnover. Journal of Applied Psychology 83: 486-93. [CrossRef]

Young, Dennis R., and Choony Kim. 2015. Can social enterprises remain sustainable and mission-focused? Applying resiliency theory. Social Enterprise Journal 11: 233-59. [CrossRef]

Zahra, Shaker A., and Gerard George. 2002. Absorptive capacity: A review, reconceptualization, and extension. Academy of Management Review 27: 185-203. [CrossRef]

Zahra, Shaker A., and Jeffrey G. Covin. 1995. Contextual influences on the corporate entrepreneurship-performance relationship: A longitudinal analysis. Journal of Business Venturing 10: 43-58. [CrossRef]

Zhou, Kevin Zheng, and Caroline Bingxin Li. 2010. How strategic orientations influence the building of dynamic capability in emerging economies. Journal of Business Research 63: 224-31. [CrossRef]

Zhou, Kevin Zheng, Chi Kin Yim, and David K. Tse. 2005. The effects of strategic orientations on technology-and market-based breakthrough innovations. Journal of Marketing 69: 42-60. [CrossRef] 